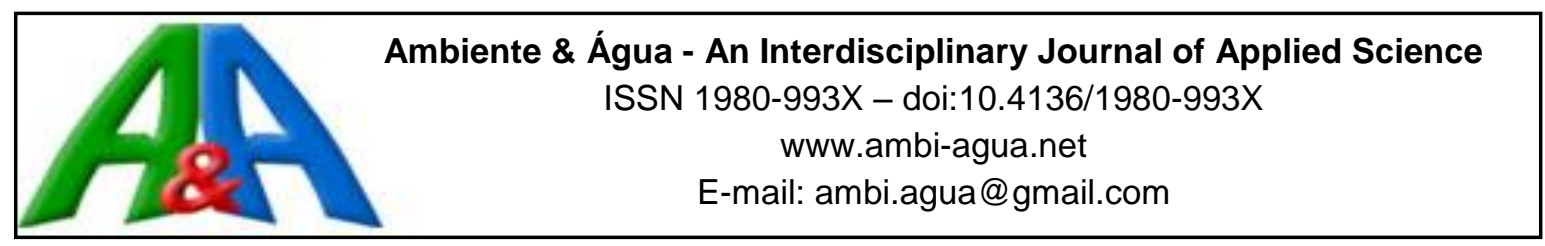

\title{
Assessment of the water quality and trophic state of the Ribeirão Guaraçau Watershed, Guarulhos (SP): a comparative analysis between rural and urban areas
}

\author{
ARTICLES doi:10.4136/ambi-agua.2170
}

Received: 27 Jul. 2017; Accepted: 16 Jan. 2018

\author{
Reinaldo Romero Vargas ${ }^{1 *}$; Márcia da Silva Barros ${ }^{2}$; Antonio Roberto Saad ${ }^{1}$; \\ Regina de Oliveira Moraes Arruda ${ }^{1}$; Fernanda Dall'Ara Azevedo ${ }^{3}$ \\ ${ }^{1}$ Universidade de Guarulhos (UNG), Guarulhos, SP, Brasil \\ Mestrado em Análise Geoambiental (MAG). E-mail: rei_vargas@terra.com.br, \\ asaad@prof.ung.br, rarruda@prof.ung.br \\ ${ }^{2}$ Centro Universitário Anhanguera de São Paulo (UNIAN), São Paulo, SP, Brasil \\ Departamento de Ciências Exatas. E-mail: barros.r777@yahoo.com.br \\ ${ }^{3}$ Universidade de Guarulhos (UNG), Guarulhos, SP, Brasil \\ Programa de Pós-Graduação em Análise Geoambiental \\ E-mail: fdallara.azevedo@gmail.com \\ *Corresponding author
}

\begin{abstract}
The urbanization process through which large urban centers have been passing has affected drastically the availability and especially the quality of water. The Ribeirão Guaraçau Watershed, located in the northern part of the Guarulhos municipality, includes rural and urban areas of different land-use classes. The goal of this study is to assess the water quality and to diagnose the eutrophication stage of the surface waters of the Ribeirão Guaraçau, the main water course of the Ribeirão Guaraçau Watershed. To assess environmental quality, physicalchemical analyses (temperature, $\mathrm{pH}$, turbidity, conductivity, and total phosphorus) and microbiological analyses $(E$. coli) were carried out during a period of 12 months. The Trophic State Index (TSI) was used to ascertain the environmental degradation conditions of lotic and lentic environments. The surface waters of the Ribeirão Guaraçau in the rural area are already compromised, with worsening of the water quality upstream indicated by high total phosphorus and E. coli caused by fecal contamination due to lack of basic sanitation in the region. Characteristic sites of the rural areas already present signs of degradation with trophic levels varying from oligotrophic to hypereutrophic. The need to provide sewage collectors and sewage treatment systems at the Bonsucesso Sewage Treatment Station, inaugurated in 2011, and the control of the occupation in areas that produce good quality water is paramount.
\end{abstract}

Keywords: eutrophication, São Paulo Metropolitan Region, urban waters, water pollution.

\section{Avaliação da qualidade da água e do estado trófico da bacia de Ribeirão Guaraçau, Guarulhos (SP): uma análise comparativa entre áreas rurais e urbanas}

\section{RESUMO}

O processo de urbanização pelo qual os grandes centros urbanos passaram afetou drasticamente a disponibilidade e, em especial, a qualidade da água. A bacia hidrográfica de 
Ribeirão Guaraçau, localizada na parte norte do município de Guarulhos, inclui áreas rurais e urbanas de diferentes classes de uso da terra. O objetivo deste estudo é avaliar a qualidade da água e diagnosticar o estágio de eutrofização das águas superficiais do Ribeirão Guaraçau, o principal curso de água da Bacia do Ribeirão Guaraçau. Para avaliar a qualidade ambiental, foram realizadas análises físico-químicas (temperatura, $\mathrm{pH}$, turbidez, condutividade e fósforo total) e análises microbiológicas (E. coli) durante um período de 12 meses. O Índice de Estado Trófico (IET) foi utilizado para determinar as condições de degradação ambiental de ambientes lóticos e lênticos. As águas superficiais do Ribeirão Guaraçau na área rural já estão comprometidas, com o piora da qualidade da água a montante indicada pelo alto fósforo total e E. coli causada por contaminação fecal devido à falta de saneamento básico na região. Os locais característicos das áreas rurais já apresentam sinais de degradação com níveis tróficos que variam de oligotróficos a hipereutróficos. A necessidade de fornecer coletores de esgoto e sistemas de tratamento de esgoto na Estação de Tratamento de Esgoto de Bonsucesso, inaugurada em 2011, e o controle da ocupação em áreas que produzem água de boa qualidade é primordial.

Palavras-chave: águas urbanas, eutrofização, poluição das águas, Região Metropolitana de São Paulo.

\section{INTRODUCTION}

The development of modern society, mainly in the urban areas, has occurred in a disordered way, devoid of any planning, and with increasing levels of environmental degradation. As a result of this disequilibrium, significant impacts can be observed, which put environmental quality at risk, notably when it comes to great metropolises. The Guarulhos Municipality, located in the Metropolitan Region of São Paulo (MRSP), is considered the second greatest city of São Paulo State. It is in full urban expansion, characterized by planning problems induced by industrial development, road, airport, utilities operations and significant civil works, for example, the construction of the northern segment of the Mario Covas Ring Highway (Oliveira et al., 2009; Mesquita, 2011).

The environmental impacts caused by deforestation, agricultural, urban and industrial development, plus the lack of basic sanitation, lead to an increase of nutrient concentrations in the aquatic ecosystems. These nutrients, especially phosphorus and nitrogen, lead to the growth of algae, including potentially toxic cyanobacteria, which endangers the ecosystem, besides increasing water treatment costs (Esteves, 2011). Such a process, named eutrophication, can be quantified by means of the Trophic State Index (TSI), which is used to classify water bodies at different trophic degrees (Lamparelli, 2004). The index classifies the water body in six trophic classes, according to the total phosphorus concentrations in water. The conditions favorable to eutrophication are those of a lentic environment, characterized by the presence of nutrients, high temperatures, high radiation levels, low turbidity and high residence time of the water. Lotic environment water bodies classified as eutrophic, supereutrophic and hypereutrophic rarely present eutrophication due to the movement of their waters. However, it is through rivers and brooks that a great part of nutrient inflow to lakes and reservoirs takes place (ANA, 2013).

Depending on the land use and occupation, different trophic levels are observed in the water bodies. Cunha et al. (2010) studied three tropical rivers with different levels of anthropic interference. These authors observed that in more-preserved regions, with $70 \%$ of the area covered by forests, the trophic levels varied from oligotrophic to mesotrophic. On the other hand, in regions occupied by industry, trophic levels were hypereutrophic. In another study of a watershed with $65 \%$ of the urbanized area characterized by the presence of stilt houses, where domestic waste is disposed of in natura in the water bodies, trophic levels varied from supereutrophic to hypereutrophic. In the same study, in another river with the presence of 
settlements and rural activity, the trophic levels varied from mesotrophic to supereutrophic (Silva et al., 2014).

Taking the concept of watershed as a study unit (Machado and Torres, 2012), the Ribeirão Guaraçau Watershed (RGW), mostly located in the northern part of the Guarulhos municipality, was selected for this study. Water producing areas are located in watershed zones (Andrade et al., 2008). Taking the municipal zoning into account, rural and urban zones are located in this watershed, each showing different forms of land use and representing foci of water quality change. The main objective of this study is the assessment of water quality and the diagnosis of the eutrophication stage of the Ribeirão Guaraçau surficial waters in rural and urban areas of the Ribeirão Guaraçau Watershed.

\subsection{Geoenvironmental characteristics of the study area}

The Guarulhos municipality is one of 39 municipalities located in the northeastern portion Metropolitan Region of São Paulo (MRSP), together with the neighboring Arujá, Itaquaquecetuba, Mairiporã, Nazaré Paulista, São Paulo and Santa Isabel municipalities (Figure 1). The municipality is characterized by a humid, subtropical climate with annual mean rainfall of $1470 \mathrm{~mm}$. The annual rainfall indices were $1897 \mathrm{~mm}$ in 2015 and $1570 \mathrm{~mm}$ in 2016 (INMET, 2016). The mean annual temperatures in the coldest months reached $17-19^{\circ} \mathrm{C}$, whereas in the summer they varied between $23^{\circ} \mathrm{C}$ and $24^{\circ} \mathrm{C}$ (Oliveira et al., 2009). The municipality is divided into five basins, the largest being the Baquirivu-Guaçu Watershed (BGW), $149 \mathrm{~km}^{2}$ in area, encompassing the study area.

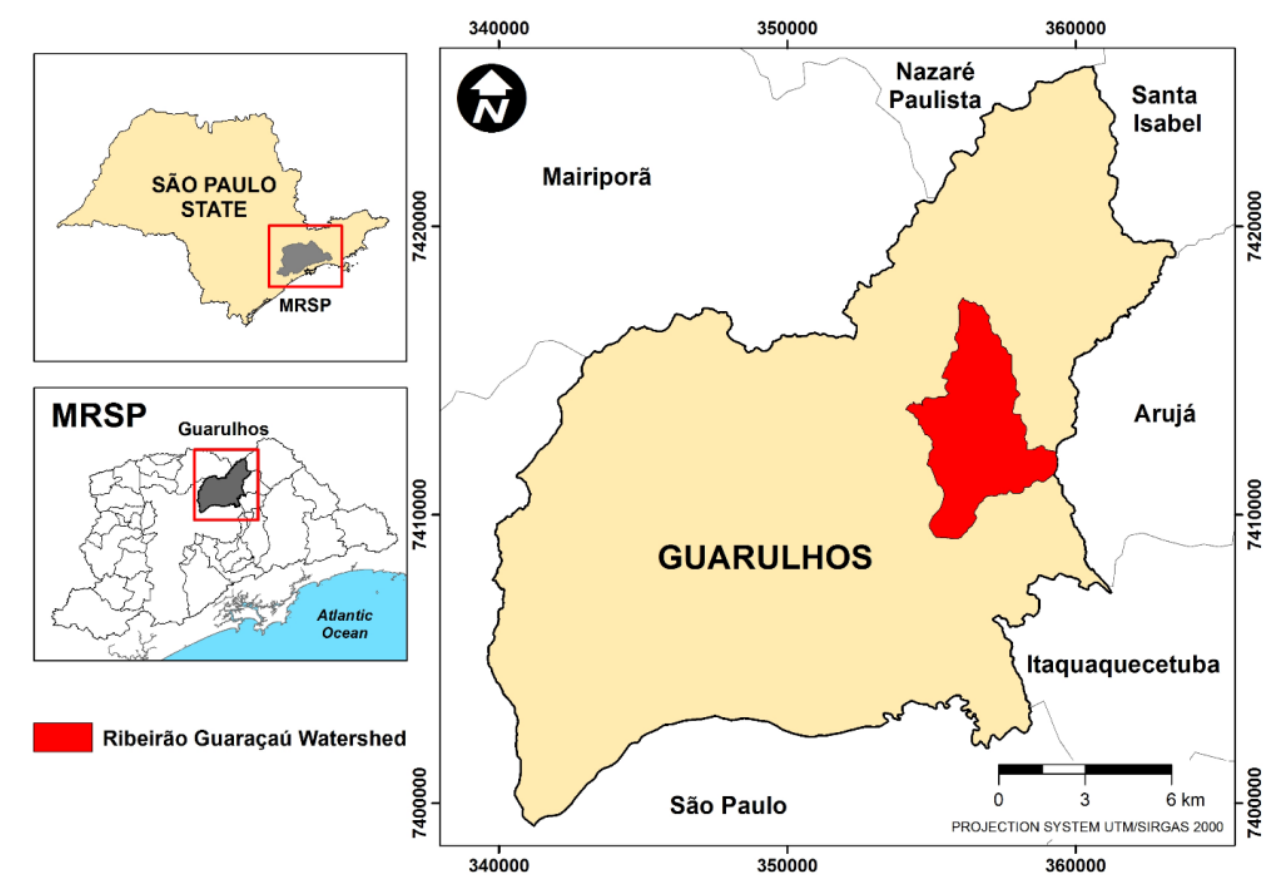

Figure 1. Location of the da Ribeirão Guaraçau Watershed (RGW), Guarulhos (SP).

Source: UnG Geoprocessing Laboratory.

The Ribeirão Guaraçau Watershed (RGW) is $20.5 \mathrm{~km}^{2}$ in area, $8350 \mathrm{~m}$ long, maximum $5600 \mathrm{~m}$ wide, and $990 \mathrm{~m}$ of maximum and $750 \mathrm{~m}$ of minimum altitude (Ribeiro et al., 2013). RGW landforms and rock types are listed in Table 1. 
Table 1. Characteristics of the Ribeirão Guaraçau Watershed (RGW) physical environment.

\begin{tabular}{|c|c|c|}
\hline \multirow{2}{*}{ ZONE } & \multicolumn{2}{|c|}{ CHARACTERISTICS DO PHYSICAL ENVIRONMENT } \\
\hline & Landforms & Rock types \\
\hline RURAL & $\begin{array}{l}\text { Mountains and hills higher than } 1000 \mathrm{~m} \\
\text { High hills higher than } 900 \mathrm{~m} \\
\text { Hillocks } \\
\text { Restricted fluvial plains }\end{array}$ & $\begin{array}{l}\text { Predominant metamorphic rocks } \\
\text { (phyllites; iron formation); } \\
\text { igneous rocks (granites); local } \\
\text { alluvial sediments. }\end{array}$ \\
\hline \multirow[b]{2}{*}{ URBAN } & Low hills & Metasediments (phyllites). \\
\hline & $\begin{array}{l}\text { Hillocks } \\
\text { Small mounds } \\
\text { Ample and restricted alluvial plains }\end{array}$ & $\begin{array}{l}\text { Clastic sediments (coarse to fine } \\
\text { sandstones; argillites); alluvial } \\
\text { sediments. }\end{array}$ \\
\hline
\end{tabular}

Source: Ribeiro et al. (2013).

\section{MATERIALS AND METHODS}

\subsection{Land-use Map}

The land-use map was prepared by upgrading the map produced by Ribeiro et al. (2013). The first step in this upgrade was to export the vector file (shapefile) of this base map to the format Keyhole Markup Language (kml) of the ArcGIS program - Version 10 (ESRI, 2013). The next step was to import from kml to Google Earth, which was overlain to an IKONOS II image, Sensor PSM, 1-m resolution, September 28, 2016, where the vertices of the vector were updated. The last step was to import the updated $\mathrm{kml}$ file to ArcGIS and export it to the shapefile format.

\subsection{Water sampling and analysis}

To assess the water quality along the Ribeirão Guaraçau, five points (P1 to P5) were selected, and six bi-monthly sampling campaigns were carried out from September 2015 to August 2016. The selection of the sampling points (Figure 2) was made considering the size of the drained surface and the different types of land use, so that points P1 to P4 are located in predominantly rural areas and point P5 in the urban zone. Point P1 (23'21'26.93' $\mathrm{S}$ and $46^{\circ} 24^{\prime} 22.60^{\prime}$ ' W) is located in a more-preserved area, with the predominance of arboreal formations. Point P2 $\left(23^{\circ} 21^{\prime} 42.98^{\prime \prime}\right.$ ' S and $46^{\circ} 24^{\prime} 16.55^{\prime}$ ' $\left.\mathrm{W}\right)$ is located at the exit of Lago Azul. Point P3 $\left(23^{\circ} 22^{\prime} 14.45^{\prime \prime} \mathrm{S}\right.$ and $\left.46^{\circ} 24^{\prime} 3.95^{\prime}, \mathrm{W}\right)$ is located in the northern portion of the watershed and receives the inflow of the households of the Água Azul neighborhood, including a high-density disordered urban occupation (slums) with no sewerage. Point P4 $\left(23^{\circ} 22^{\prime} 50.74^{\prime}\right.$ ' S and $46^{\circ} 23^{\prime} 44.67^{\prime}$ ' W), although located in an agricultural area surrounded by vegetated areas, it gathers the contributions from the upstream points. Point P5 $\left(23^{\circ} 24^{\prime} 3.14^{\prime \prime} \mathrm{S}\right.$ and $46^{\circ} 24^{\prime} 0.82^{\prime}$ ' $\mathrm{W}$ ) is located in area characterized by high-density, ordered urban occupation.

Water analysis in the field was performed using properly calibrated analytical instruments and obtaining triplicate measurements for the following physico-chemical parameters: Temperature (Digimed DM-3 conductivity meter), $\mathrm{pH}$ (Digimed DM-2 pH meter), Conductivity (Digimed DM-3 conductivity meter), and Turbidity (Quimis Q279P turbidimeter). The other samples were collected following the National Guide for Collecting and Preservation of Samples (ANA, 2011) for Total Phosphorus and Escherichia coli, analyzed in triplicate, as recommended by the Standard Methods for Examination of Water and Wastewater (APHA et al., 2012). 


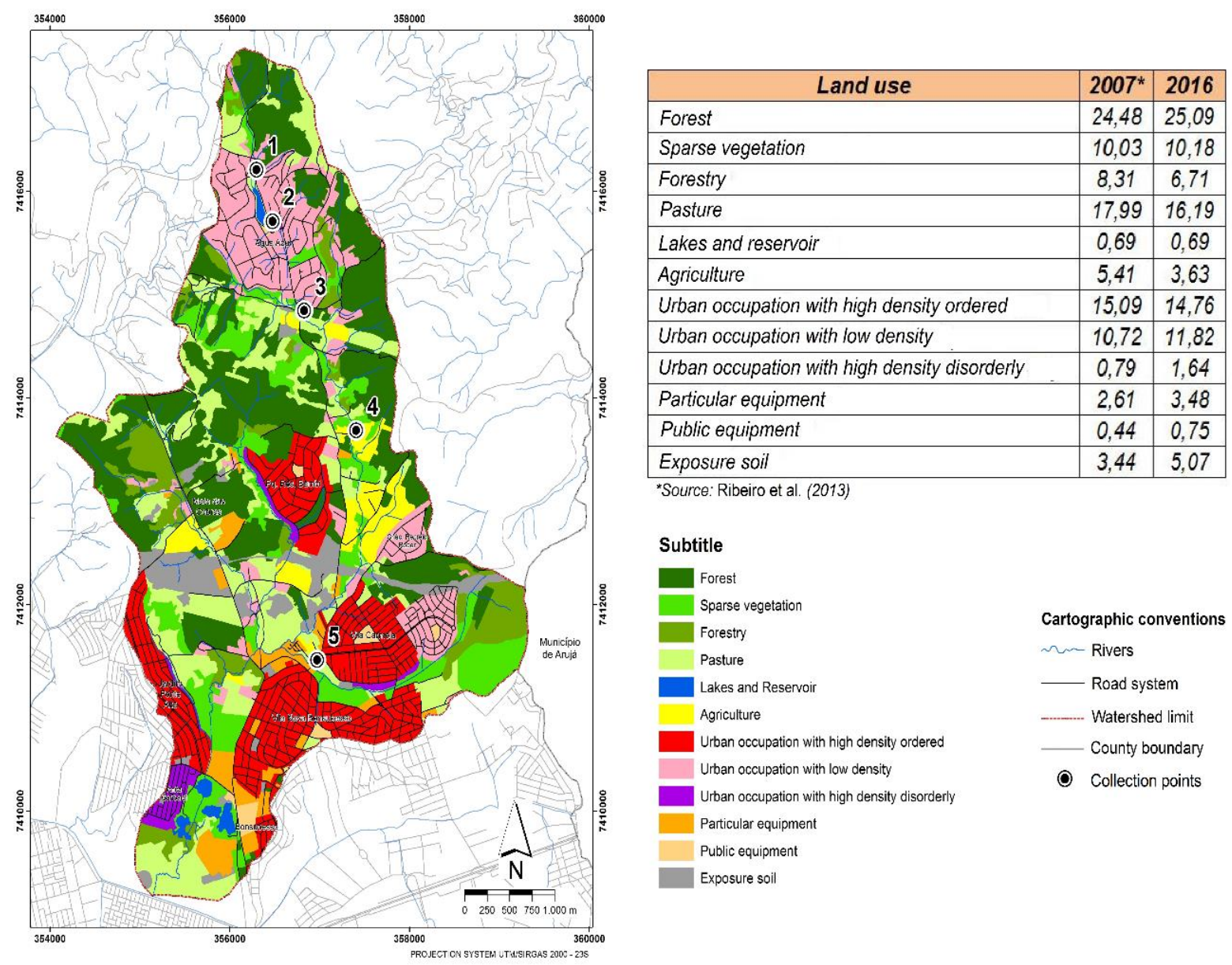

Figure 2. Land-use and occupation map for 2016, with the location of the water-sampling points and land-use classes and their percentages (\%) in the Ribeirão Guaraçau Watershed (RGW) in 2007 and 2016.

Source: UnG Geoprocessing Laboratory.

The results of these analyses were compared to standards established by CONAMA Resolution 357/2005 (CONAMA, 2005) and State Decree \#10755, which assigns water bodies to the classification provided by the State Decree \#8468, dated September 8, 1976. The Baquirivu-Guaçu River and all its tributaries up to the confluence with the Tietê River in the Guarulhos municipality belong to Class 3 (São Paulo, 1977). This class of water is destined for the supply for human consumption, after conventional or advanced treatment; irrigation of tree and forage crops; amateur fishing; secondary contact recreation; and animal watering.

\subsection{Trophic State Index (TSI)}

The calculation of TSI (TP), according to Lamparelli's (2004) methodology, took into account total phosphorus (TP) measured at points P1 to P5 $\left(\mu \mathrm{g} . \mathrm{L}^{-1}\right)$.

The TSI values are distributed in the six trophic state classes as follows (CETESB, 2007; Lamparelli, 2004): TSI $\leq 47$ (ultraoligotrophic); $47 \quad<$ TSI $\leq 52$ (oligotrophic); $52<$ TSI $\leq 59$ (mesotrophic); $59<\mathrm{TSI} \leq 63$ (eutrophic); $63<\mathrm{TSI} \leq 67$ (supereutrophic), and TSI >67 (hypereutrophic).

\section{RESULTS AND DISCUSSION}

The Ribeirão Guaraçau Watershed (RGW) contemplates zones with both rural and urban characteristics. From Point P1 to Point P4, arboreal formations, grassy vegetation and low- 
density urban occupations predominate, which characterizes this region as a rural area (Figure 2). The consolidated urban zone predominantly occupies the southern portion of the basin. In the surroundings of Point P5, which is the last sampling point of the Ribeirão Guaraçau, there are high-density, ordered urban occupations, which are essentially of urban characteristics. During the last ten years, from 2007 to 2016, RGW has undergone little changes regarding occupation (Figure 2). A negative aspect is that in this period, despite the minor contribution of the high-density disordered occupations (slums), there has been an increase of approximately $108 \%$ of this type of occupation along RGW, from the rural to the urban area. The increase of these areas devoid of sewage collecting systems has led to the worsening of the quality of the watershed water bodies. Another relevant change regarding water quality was the $33 \%$ decrease in agricultural areas. The land-use and occupation map shows that the majority of the agricultural areas were replaced by grassy vegetation in 2007, as reported by Ribeiro et al. (2013). However, there was not an increase of grassy vegetation areas, due to the $10 \%$ increase of low-density urban occupations in the rural region.

Upstream Point P1, which is located in a low-density urban occupation area, a more preserved region is composed of arboreal formations. As a consequence, all the measured parameters indicate the very good quality of the surficial waters (Table 2). Only the mean value of the microbiological parameter (E. coli) is above the established in the CONAMA Resolution for Class 3 water bodies (CONAMA, 2005). This high value is explained by the fact that there are small animal farms surrounding Point 1 . The total phosphorus analysis for this point, despite being below the limit established in the legislation, yielded a mean value close to the limit and a maximum value above the limit. Even though it is not high, this corroborates the fecal contamination of the water body, probably caused by animal feces.

Water temperature (Table 2) varied according to the occupation of the surroundings, the lowest mean value being obtained at Point P1 and corresponding to the most vegetated area, and the highest at Point P5, corresponding to the urban area. Several studies indicate that the presence of a vegetated area in the surroundings of a water body causes a decrease in water temperatures. Conversely, more urbanized areas with little vegetation significantly increase water temperature (Fia et al., 2015; Vargas et al., 2015; Pereira et al., 2016; Carvalho et al., 2016).

For all the analyzed points, $\mathrm{pH}$ did not vary significantly along the watershed, with low coefficient of variation and mean $\mathrm{pH}$ values within the limits established by CONAMA Resolution 357/05, even in areas characterized by industrial activity, agriculture and lack of basic sanitation.

Turbidity values for points P1 to P4 are below the maximum limit established by CONAMA 357/05. However, turbidity values for Point P5 exceeded the limit, due to the fact that domestic and chemical industrial wastes are discharged in the Ribeirão Guaraçau. The highest turbidity values were found in the rainy season, which was also observed by Sardinha et al. (2008), Ríos-Villamizar et al. (2011), Fia et al. (2015) and Andrietti et al. (2016). In this period the dragging of solids in suspension occurs by means of runoff processes, mainly in regions with exposed soil in the proximity of water bodies.

Many studies have reported the use of electric conductivity to assess the impact of pollutants in the aquatic environment, both rivers (Uwidia and Ukulu, 2013; Thompson et al., 2012; Vargas et al., 2015) and lakes (Das et al., 2006; Costa and Henry, 2010). The water of each region presents characteristic electric conductivity, which depends mainly on the rock types the water permeates (Tong and Chen, 2002). Mean conductivity values increased from Point P1 to Point P5 (Table 2), which indicates an increase of ion concentrations upstream to downstream. It is worth mentioning the high conductivity value $(860 \mu \mathrm{S} / \mathrm{cm})$ at Point P4, located in an agricultural area. The use of fertilizers, such as inorganic nitrogen and phosphorus salts, leads to an increase 
in conductivity at P4. This can also be confirmed by the increase in total phosphorus (TP) at this Point P4 in relation to Point P3 (Table 2). The contribution of other water bodies between Points P4 and P5 causes the decrease of conductivity by dilution at Point P5 (671 $\mu$ S.cm-1). Vargas et al. (2015) obtained similar results for the Córrego Taquara do Reino, which belongs to the homonymous watershed located north of the Guarulhos municipality. According to the authors, the lack of basic sanitation caused an increase in electric conductivity.

Table 2. Values of the physical-chemical and microbiologic parameters of Ribeirão Guaraçau Watershed waters from September 2015 to August 2016.

\begin{tabular}{|c|c|c|c|c|c|c|c|}
\hline Parameter & Points & Mean & s.d. & Min. & Max. & $\mathrm{CV}(\%)$ & CONAMA 357 Class 3 \\
\hline \multirow{5}{*}{$\mathrm{T}\left({ }^{\circ} \mathrm{C}\right)$} & $\mathrm{P} 1$ & 18.5 & 4.2 & 13.0 & 24.3 & 22.9 & \multirow{5}{*}{ N.E. } \\
\hline & $\mathrm{P} 2$ & 20.9 & 4.3 & 14.5 & 26.0 & 20.7 & \\
\hline & P3 & 20.7 & 4.0 & 14.9 & 24.9 & 19.5 & \\
\hline & $\mathrm{P} 4$ & 19.5 & 4.2 & 13.6 & 23.9 & 21.6 & \\
\hline & P5 & 21.8 & 4.0 & 15.3 & 25.6 & 18.5 & \\
\hline \multirow{5}{*}{$\mathrm{pH}(\mathrm{upH})$} & $\mathrm{P} 1$ & 6.1 & 0.4 & 5.6 & 6.6 & 5.8 & \multirow{5}{*}{6 to 9} \\
\hline & $\mathrm{P} 2$ & 6.9 & 0.4 & 6.5 & 7.5 & 5.8 & \\
\hline & P3 & 7.3 & 0.8 & 5.98 & 8.1 & 11.4 & \\
\hline & $\mathrm{P} 4$ & 7.5 & 0.6 & 6.9 & 8.4 & 7.7 & \\
\hline & P5 & 7.0 & 0.7 & 6.5 & 8.3 & 10.7 & \\
\hline \multirow{5}{*}{ TU (NTU) } & $\mathrm{P} 1$ & 10 & 15 & 2 & 40 & 152 & \multirow{5}{*}{$\max .100$} \\
\hline & $\mathrm{P} 2$ & 22 & 20 & 2 & 55 & 88 & \\
\hline & P3 & 30 & 11 & 12 & 39 & 36 & \\
\hline & $\mathrm{P} 4$ & 14 & 10 & 2 & 30 & 68 & \\
\hline & P5 & 206 & 204 & 32 & 532 & 99 & \\
\hline \multirow{5}{*}{$\mathrm{CE}\left(\mu \mathrm{S} . \mathrm{cm}^{-1}\right)$} & $\mathrm{P} 1$ & 83 & 24 & 51 & 107 & 28.6 & \multirow{5}{*}{ N.E. } \\
\hline & $\mathrm{P} 2$ & 138 & 23 & 115 & 172 & 16.5 & \\
\hline & $\mathrm{P} 3$ & 242 & 107 & 156 & 457 & 44.4 & \\
\hline & $\mathrm{P} 4$ & 860 & 415 & 446 & 1603 & 48.3 & \\
\hline & P5 & 671 & 235 & 421 & 956 & 35 & \\
\hline \multirow{5}{*}{ TP (mg. $\left.\mathrm{L}^{-1}\right)$} & $\mathrm{P} 1$ & 0.117 & 0.197 & 0.007 & 0.5 & 168 & \multirow{3}{*}{0.05 (lentic) } \\
\hline & $\mathrm{P} 2$ & 0.123 & 0.285 & 0.007 & 0.71 & 231 & \\
\hline & $\mathrm{P} 3$ & 1.88 & 2.1 & 0.007 & 5.14 & 112 & \\
\hline & $\mathrm{P} 4$ & 2.54 & 1.58 & 0.007 & 4.18 & 63 & \multirow{2}{*}{0.15 (lotic) } \\
\hline & P5 & 4.84 & 3.57 & 0.13 & 9.32 & 74 & \\
\hline \multirow{5}{*}{ E. coli $\left(\mathrm{UFC} .100 \mathrm{~mL}^{-1}\right)$} & $\mathrm{P} 1$ & $4.7 E+03$ & $2.2 \mathrm{E}+03$ & $2.5 \mathrm{E}+03$ & $8.0 \mathrm{E}+03$ & 47 & \multirow{5}{*}{$\max .2400$} \\
\hline & $\mathrm{P} 2$ & $6.3 \mathrm{E}+03$ & $4.1 \mathrm{E}+03$ & $2.4 \mathrm{E}+03$ & $1.3 \mathrm{E}+04$ & 65 & \\
\hline & P3 & $5.5 \mathrm{E}+05$ & $1.1 \mathrm{E}+06$ & $1.2 \mathrm{E}+04$ & $2.8 \mathrm{E}+06$ & 205 & \\
\hline & $\mathrm{P} 4$ & $7.9 \mathrm{E}+05$ & $1.1 \mathrm{E}+06$ & $1.2 \mathrm{E}+05$ & $3.0 \mathrm{E}+06$ & 145 & \\
\hline & P5 & $2.2 \mathrm{E}+07$ & $2.3 \mathrm{E}+07$ & $3.0 \mathrm{E}+06$ & $5.4 \mathrm{E}+07$ & 104 & \\
\hline
\end{tabular}

P2 lentic body (Lago Azul). The other points: lotic body.

Abbreviations: s.d. (standard deviation); CV (coefficient of variation); T (temperature); TU (turbidity); CE (electric conductivity); TP (total phosphorus); E. coli (Escherichia coli); N.E (Not established).

Ribeirão Guaraçau reaches other water courses that flow towards the Lago Azul, which was an old open pit for sand exploitation (Mesquita, 2011). At present, the lake is used for recreation, such as swimming and fishing. At Point P2, total phosphorus values for lentic bodies and especially the microbiologic parameter exceeded the values established by the legislation. Fecal contamination from regular and irregular occupations, plus the lack of sewerage and farming lead to the values above those permitted by legislation and certainly this demands attention from municipal authorities, given that the use of Lago Azul for recreational activities is encouraged by them. Point P3, in the northern portion of the watershed, is the confluence of contributions from households of the Água Azul neighborhood, in particular the high-density 
disordered urban occupation (slums) with no sewerage. Such a degradation scenario is confirmed when comparing Point P2 to Point P3. There is an increase of 15 times in total phosphorus mean concentration and 87 times in $E$. coli mean values. These values continuously increase along the basin, and the highest values are found at Point P5, which receives the inflow of urban area located in neighborhoods Chácara Recreio Rober and Vila Carmela.

The behavior of total phosphorus and E. coli was distinct during rainy periods. Total phosphorus values were higher during dry periods, with the exception of Point $\mathrm{P} 4$, indicating that in rainy periods dilution of phosphorus concentrations takes place in the surficial waters. The mean total phosphorus values and standard deviations for the dry and rainy periods were respectively at $\mathrm{P} 1: 0.176 \pm 0.281$ and $0.059 \pm 0.089$; at $\mathrm{P} 2: 0.240 \pm 0.403$ and $0.007 \pm 0.000$; at P3: $2.577 \pm 2.335$ and $1.175 \pm 2.023$; at P4: $2.463 \pm 1.056$ and $2.607 \pm 2.268$, and at P5: 5.350 \pm 3.838 and $4.329 \pm 4.035$. The very close phosphorus values at Point P4 can be related to the constant use of fertilizers in the agricultural area (Figure 2). Saad et al. (2013) also observed the dilution effect in total phosphorus concentrations during rainy periods and, according to the authors, this effect was more pronounced in the consolidated urban area and impervious soil. Peláez-Rodríguez (2001) also observed an increase in the concentration of nutrients during the dry season and attributed this fact to the increase in nutrient concentration due to decrease in water flow. Similarly, Stacciarini (2002), when assessing the quality of the water resources in Paulínia (State of São Paulo), observed that in the majority of the points he analyzed phosphorus concentrations were higher in the dry period. Cruz (2003), assessing the quality of the Uberaba River waters (State of Minas Gerais), obtained the same trends regarding total phosphorus in rainy and dry periods.

Farage et al. (2010) observed in the region of the Pombas River (State of Minas Gerais) that during the rainy period, runoff in anthropized areas contributed to a higher discharge of phosphorus, increasing its concentration, even with higher river flows. The authors attributed this increase in total phosphorus to runoff occurring in the rainy periods mainly on soils devoid of vegetation or with predominant grassy cover, as on the margins of the Pomba River. According to Prada and Oliveira (2006), the increase in phosphorus in river waters during the rainy period can also be related to the re-suspension of bottom sediments as the river flow increases.

The amount of microorganisms present in surficial waters was higher in the rainy period, in special at the least-preserved points, as indicated by the $E$. coli logarithmic values during the rainy and dry periods, respectively for P3: $5.36 \pm 1.20$ and $4.46 \pm 0.14$; for P4: $5.96 \pm 0.55$ and $5.14 \pm 0.10$, and for P5: $7.25 \pm 0.41$ and $6.92 \pm 0.70$. Saad et al. (2013) obtained similar results for the Ribeirão Tanque Grande Watershed, which presents geomorphological characteristics similar to those of RGW. Due to the higher declivity, runoff takes place with the transport of microorganisms to the water bodies, preventing water infiltration in the soil (Chaves and Santos, 2009; De Azevedo Lopes and Magalhães Júnior, 2010; Andrietti et al., 2016).

The Trophic State Index was calculated using total phosphorus (TP) values. Figure 3 shows that TSI values increase from rural to urban zones. 


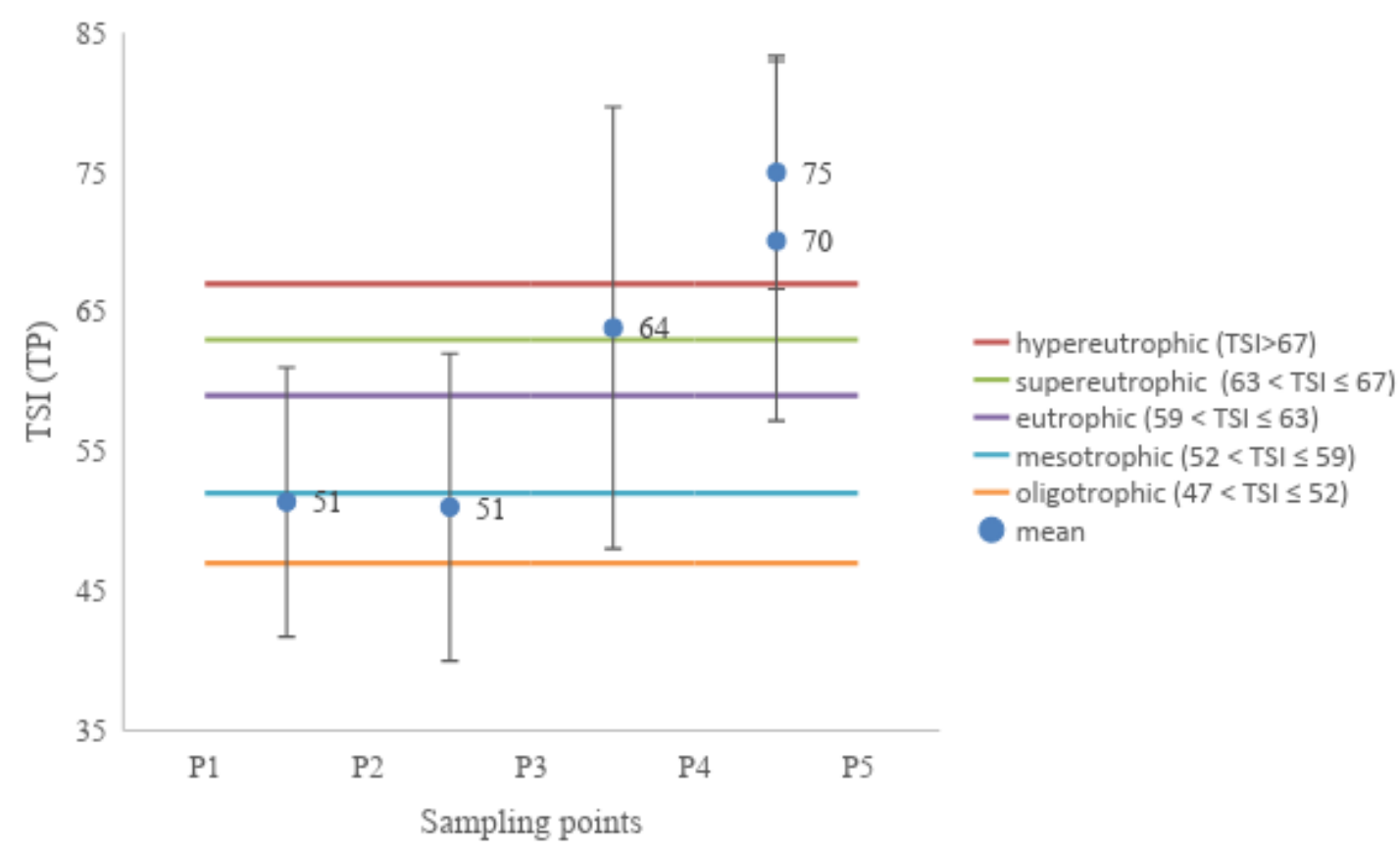

Figure 3. Trophic State Index behavior along Ribeirão Guaraçau Watershed from September 2015 to August 2016.

In Points P1 and P2, which are the most-preserved, trophic state levels vary from oligotrophic to mesotrophic, indicating the presence of clean water bodies, in which unwanted interferences resulting from the presence of nutrients, in special phosphorus, do not occur. For the other points, progressive worsening of the water body trophic state is observed (Figure 3 ). In the rainy periods, TSI (TP) values were favorably lower, thanks to the dilution of the nutrients. For Point P3, the supereutrophic level predominates, but with ample variation from oligotrophic to hypereutrophic. The presence of small farms and the irregular occupation in the surroundings of Point P3, plus the temporal effect, besides the paving works during the sampling period, caused such variations in the trophic level. Similar results were obtained by Saad et al. (2013) and Vargas et al. (2015) for other watersheds of the Guarulhos municipality. The trophic levels at Point P4 got worse, varying from eutrophic to hypereutrophic. Agricultural activities close to this point cause the worsening of the trophic level, due to contamination by fertilizers used in plantations (Farage et al., 2010; Gonçalves and Rocha, 2016; Zhou et al., 2016). Point P5 reached hypereutrophic levels in all determinations, indicating a water body significantly affected by high organic matter and nutrient concentrations, compromising the use of the water at that point.

\section{CONCLUSIONS}

The recent hydric crisis that affected the southeastern region of Brazil from 2014 to 2016 and that still affects a large part of the Brazilian northeastern region calls attention to preservation policies and control of watershed areas. The expansion of urban areas towards these watershed areas directly affects the quality of surficial and underground waters, in particular in developing countries due mainly to the lack of sewage treatment, which is directly discharged in rivers, causing pollution and impacts on the environment. Urbanization favors impermeabilization of the soil, leading to flooding and making aquifer recharge difficult. Several areas in the northern part of the Guarulhos municipality produce water but unfortunately the studies of the watersheds, in particular of the Baquirivu-Guaçu River Watershed, have pointed to the degradation of the water bodies. The present study of the Ribeirão Guaraçau Watershed shows that the Ribeirão Guaraçau surficial waters in the rural area are already compromised in the surroundings of the Lago Azul (point P2). The other points, 
$\mathrm{P} 3$ to $\mathrm{P} 5$, reveal the worsening of the water quality in respect to total phosphorus and $E$. coli, indicating fecal contamination due to the lack of basic sanitation. The increase of disordered developments close to Lago Azul has contributed to the worsening of the water quality. The values of both parameters at these sampling points exceeded the limit established by CONAMA Resolution 357/05 for Class 3 water bodies. Points P3 and P4 in the rural zone present signs of degradation, with trophic levels varying from oligotrophic to hypereutrophic and predominance of the supereutrophic level at Point P3, and worse conditions at Point P4, with the predominance of the hypereutrophic level and variations from eutrophic to hypereutrophic.

The Bonsucesso Sewage Treatment Station, located downstream from the Ribeirão Guaraçau Watershed, was inaugurated in December 2011 to attend to a sewage treatment demand for 260 thousand inhabitants (SAAE, 2013). The necessity to build a collecting net and sewage treatment installations in the Bonsucesso Station is herein emphasized (Vargas et al., 2017).

\section{ACKNOWLEDGMENTS}

To São Paulo Research Foundation for the financial support to Research Project Proc. 2015/07406-4.

\section{REFERENCES}

AGÊNCIA NACIONAL DE ÁGUAS (Brasil). Guia nacional de coleta e preservação de amostras: água, sedimento, comunidades aquáticas e efluentes líquidos. São Paulo: CETESB; Brasília: ANA, 2011.

AGÊNCIA NACIONAL DE ÁGUAS (Brasil). Conjuntura dos recursos hídricos no Brasil: 2013. Brasília, 2013.

ANDRADE, M. R. M.; OLIVEIRA, A. O.; QUEIROZ, E.; SATO, S. E.; BARROS, E. J.; BAGATTINI, G. et al. Aspectos fisiográficos da paisagem guarulhense. In: OMAR, E. E. H. (Org.) Guarulhos tem história: questões sobre história natural, social e cultural. São Paulo: Ananda, 2008. p. 25-37.

ANDRIETTI, G.; FREIRE, R.; DO AMARAL, A. G.; DE ALMEIDA, F. T.; BONGIOVANI, M. C.; SCHNEIDER, R. M. Índices de qualidade da água e de estado trófico do rio Caiabi, MT/Water quality index and eutrophication indices of Caiabi River, MT. Revista Ambiente \& Água, v. 11, n. 1, p. 162 - 175, 2016. http://dx.doi.org/10.4136/ambiagua. 1769

AMERICAN PUBLIC ASSOCIATION - APHA; AMERICAN WATER WORKS ASSOCIATION - AWWA; WATER ENVIRONMENT FEDERATION - WEF. Standard Methods for Examination of Water and Wastewater. 21 ed. Washington, 2012.

CARVAlHO, A. de P.; BALDUINO, Â. R.; MACIEL, G. F.; PICANÇO, A. P. Avaliação da poluição em rios utilizando índices de qualidade da água: um estudo de caso no Ribeirão São João em Porto Nacional-TO. Geociências (São Paulo), v. 35, n. 3, p. 472-484, 2016.

CONSELHO NACIONAL DO MEIO AMBIENTE - CONAMA (Brasil) Resolução $n^{\circ} 357$ de 17 de março de 2005. Dispõe sobre a classificação dos corpos de água e diretrizes ambientais para o seu enquadramento, bem como estabelece as condições e padrões de lançamento de efluentes, e dá outras providências. Diário Oficial [da] União, Brasilia, DF, 17 mar. 2005. 
COMPANHIA AMBIENTAL DO ESTADO DE SÃO PAULO - CETESB. Relatório de qualidade das águas interiores no estado de São Paulo: 2006. São Paulo, 2007.

CHAVES, H. M. L.; SANTOS, L. B. Ocupação do solo, fragmentação da paisagem e qualidade da água em uma pequena bacia hidrográfica. Revista Brasileira de Engenharia Agrícola e Ambiental, v. 13, p. 922-930, 2009.

COSTA, M. L. R.; HENRY, R. Phosphorus, nitrogen, and carbon contents of macrophytes in lakes lateral to a tropical river (Paranapanema River, São Paulo, Brazil). Acta Limnologica Brasiliensia, v. 22, n. 2, p. 122-132, 2010. http://dx.doi.org/10.4322/actalb.02202002

CUNHA, D. G. F.; BOTTINO, F.; CALIJURI M. C. Land use influence on eutrophicationrelated water variables: case study of tropical rivers with different degrees of anthropogenic interference. Acta Limnologica Brasiliensia, v. 22, n. 1, p. 35-45, 2010. http://dx.doi.org/10.4322/actalb.02201005

CRUZ, L. B. S. Diagnóstico ambiental da bacia do Rio Uberaba, MG. 2003. 180f. Tese (Doutorado em Água e Solo) -Faculdade de Engenharia Agrícola, Universidade Estadual de Campinas, 2003.

DAS, R.; SAMAL, N. R., ROY, P. K.; MITRA, D. Role of Electrical Conductivity as an Indicator of Pollution in Shallow Lakes. Asian Journal of Water, Environment and Pollution, v. 3, n 1, p. 143-146, 2006.

DE AZEVEDO LOPES, F. W.; MAGALHÃES JR., A. P. M. Influência das condições naturais de $\mathrm{pH}$ sobre o índice de qualidade das águas (IQA) na bacia do Ribeirão de Carrancas. Geografias, v. 6, n. 2, p. 134-147, 2010.

ENVIRONMENTAL SYSTEMS RESEARCH INSTITUTE - ESRI. ArcGIS Professional GIS for the desktop, version 10.0. Redlands, 2013.

ESTEVES, F.A. Fundamentos de Limnologia. 3. ed. São Paulo: Interciência, 2011.

FARAGE, J. D. A. P.; MATOS, A. T.; SILVA, D. D.; BORGES, A. C. Determinação do índice de estado trófico para fósforo em pontos do rio Pomba. Revista Engenharia na Agricultura, v. 18, n. 4, p. 322-329, 2010. https://doi.org/10.13083/reveng.v18i4.98

FIA, R.; TADEU, H.C.; MENEZES, J. P. C; FIA, F. R. L; OLIVEIRA, L. F. C. Qualidade da água de um ecossistema lótico urbano. Revista Brasileira de Recursos Hídricos, v.20, n. 2 , p. $267-275,2015$.

GONÇALVES, D. R. P.; ROCHA, C. H. Indicadores de qualidade da água e padrões de uso da terra em bacias hidrográficas no Estado do Paraná. Pesquisa Agropecuária. Brasileira, v. 51, n. 9, p. 1172-1183, 2016.

INSTITUTO NACIONAL DE METEOROLOGIA - INMET. BDMEP - Banco de Dados Meteorológicos para Ensino e Pesquisa. Available at http://www.inmet.gov.br/portal/index.php?r=bdmep/bdmep. Accessed on: 18th October 2016.

LAMPARELLI, M. C. Grau de trofia em corpos d'água do estado de São Paulo: avaliação dos métodos de monitoramento. 2004. 235f. Tese (Doutorado), Instituto de Biociências, Universidade de São Paulo, São Paulo, 2004. 
MACHADO, P. J. O.; TORRES, F. T. P. Introdução à Hidrogeografia. São Paulo: Cengage Learning, 2012.

MESQUITA, M. V. Degradação do meio físico em loteamento nos bairros Invernada, Fortaleza e Água Azul, como estudos de casos da expansão urbana do município de Guarulhos (SP). 2011. Tese (Doutorado) - Instituto de Geociências e Ciências Exatas, Universidade Estadual Paulista Júlio de Mesquita Filho, Rio Claro, 2011.

OLIVEIRA, A. M. S.; ANDRADE, M. R. M.; QUEIROZ, W.; SATO, S. Bases Geoambientais para um Sistema de Informações Ambientais do Município de Guarulhos. Guarulhos: Universidade Guarulhos, 2009. p. 179.

PELÁEZ-RODRÍGUEZ, M. Avaliação da qualidade da água da Bacia do Alto JacaréGuaçú - SP (Ribeirão do Feijão e Rio Monjolinho) através de varáveis Físicas, Químicas e Biológicas. 2001. 144f. Tese. (Doutorado em Ciências da Engenharia. Ambiental) - Universidade de São Paulo, São Carlos, 2001.

PEREIRA, B. W. de F.; MACIEL, M. D. N. M.; DE ASSIS OLIVEIRA, F.; DA SILVA ALVES, M. A. M.; RIBEIRO, A. M.; FERREIRA, B. M. et al.. Uso da terra e degradação na qualidade da água na bacia hidrográfica do rio Peixe-Boi, PA, Brasil/Land use and water quality degradation in the Peixe-Boi River watershed. Revista Ambiente \& Água, v. 11, n. 2, p. 472, 2016. http://dx.doi.org/10.4136/ambi-agua.1802

PRADA, S. M.; OLIVEIRA, E. de. Distribuição de nutrientes (C, N e P) em testemunhos de sedimentos do reservatório das Garças, Cotia - SP. In: REUNIÃO ANUAL DA SOCIEDADE BRASILEIRA DE QUÍMICA, 29., 2006, São Paulo. Anais... Available at http://sec.sbq.org.br/cd29ra/resumos/T1855-2.pdf. Accessed on: 18th October 2016.

RIBEIRO, T. F. B.; ANDRADE, M. R. M.; SATO, S. E.; Dos SANTOS, M. T.; SAAD, A. R. Análise geoambiental da bacia hidrográfica do Ribeirão Guaraçau, Guarulhos (SP), com base no mapa de uso da terra e aspectos morfométricos. Revista Universidade Guarulhos. Geociências, v. 12, n. 1, p. 49 -62, 2013.

RÍOS-VILLAMIZAR, E. A.; MARTINS JUNIOR, A. F.; WAICHMAN, A. V. Caracterização físico-química das águas e desmatamento na bacia do rio Purus, Amazônia Brasileira Ocidental. Revista Geografia Acadêmica, v. 5, n. 2, p. 54-65, 2011.

SAAD, A. R.; VARGAS, R. R.; LOPES, J. C.; ARRUDA, R. O. M.; QUEIROZ, W. Índice de estado trófico da bacia hidrográfica do Ribeirão Tanque Grande, Guarulhos (SP): análise comparativa entre as zonas rural e urbana. Geociências, v. 32, n. 4, p. 611-624, 2013.

SERVIÇO AUTÔNOMO DE ÁGUA E ESGOTO DE GUARULHOS - SAAE. 2013. Sistema de esgoto. Available at: http://www.saaeguarulhos.sp.gov.br:8081/sistema-de-esgoto. Accessed on 19th September 2016.

SÃO PAULO. Decreto no 10.755, de 22 de novembro de 1977. Dispõe sobre o enquadramento dos corpos de água receptores na classificação prevista no Decreto no 8.468, de 8 de setembro de 1976, e dá providências correlatas. Diário Oficial [do] Estado, São Paulo, 1977.

SARDINHA, D. S.; CONCEIÇÃO, F. T.; SOUZA, A. D. G.; SILVEIRA, A.; JULIO, M.; GONÇALVES, J. C. S. I. Avaliação da qualidade da água e autodepuração do Ribeirão do Meio, Leme (SP). Engenharia Sanitária e Ambiental, v. 13, n.3, p. 329-338, 2008. 
SILVA, G. S.; SANTOS, E. A.; CORRÊA, L. B.; MARQUES, A. L. B.; MARQUES, E. P.; SOUSA, E. R. et al. Avaliação integrada da qualidade de águas superficiais: grau de trofia e proteção da vida aquática nos rios Anil e Bacanga, São Luís (MA). Engenharia Sanitária Ambiental v. 19, n. 3, p. 245-251, 2014. http://dx.doi.org/10.1590/S141341522014019000000438

STACCIARINI, R. Avaliação da qualidade dos recursos hídricos junto ao Município de Paulínia, Estado de São Paulo, Brasil. 2002. 214f. Tese (Doutorado) - Faculdade de Engenharia Agricola, Universidade Estadual de Campinas, Campinas, 2002.

THOMPSON, M. Y.; BRANDES, D.; KNEY, A. D. Using electronic conductivity and hardness data for rapid assessment of stream water quality. Journal of Environmental Management, v. 104, p. 152-157, 2012. https://doi.org/10.1016/j.jenvman.2012.03.025

TONG, S. T. Y.; CHEN, W. Modeling the relationship between land use and surface water quality. Journal of Environmental Management, v. 66, p. 377-393, 2002. https://doi.org/10.1006/jema.2002.0593

UWIDIA, I. E.; UKULU, H. S. Studies on electrical conductivity and total dissolved solids concentration in raw domestic wastewater obtained from an estate in Warri, Nigeria. Greener Journal of Physical Sciences. v. 3, n. 3, p. 110-114, 2013.

VARGAS, R. R.; SAAD, A. R.; DALMAS, F. B.; ROSA, A.; ARRUDA, R. O. M.; MESQUITA, M. V. et al. Water Quality Assessment in the Córrego Taquara do Reino Watershed, Guarulhos Municipality (São Paulo State - Brazil): Effects of Environmental Degradation. Anuário do Instituto de Geociências, v. 38, n. 2, p. 137-144, 2015.

VARGAS, R. R.; GONÇALVES, J. J. S.; DALMAS, F. D.; SAAD, A. R.; ARRUDA, R. O. M.; FERREIRA, A. T. S. The contribution of the Guarulhos Municipality (São Paulo State) to the water quality of the Alto Tietê System. Pesquisas em Geociências, v. 44, n. 1, p. 109$121,2017$.

ZHOU, P.; HUANG, J.; PONTIUS JÚNIOR, R. G.; HONG, H. New insight into the correlations between land use and water quality in a coastal watershed of China: Does point source pollution weaken it? Science of the Total Environment, v. 543, p.591-600, 2016. https://doi.org/10.1016/j.scitotenv.2015.11.063 